\title{
EFFECT OF GONADOTROPHIN-RELEASING HORMONE AND HUMAN CHORIONIC GONADOTROPHIN ON THE RESPONSE OF THE EWE TO PREGNANT MARE SERUM GONADOTROPHIN
}

\author{
J. F. QUIRKE AND J. P. HANRAHAN \\ The Agricultural Institute, Ballinrobe, Co. Mayo, Ireland
}

(Received 5th October 1974)

An experiment was conducted to determine whether gonadotrophin-releasing hormone (Gn-RH) or HCG would reduce the proportion of unruptured follicles in the Galway ewe following a high superovulating dose of PMSG given in conjunction with a progestagen to synchronize oestrus.

Forty-four Galway ewes aged $1 \frac{1}{2}$ to 5 years (average wt $64.7 \mathrm{~kg}$ ) were treated with intravaginal pessaries impregnated with $30 \mathrm{mg}$ 'cronolone' (Synchromate: G. D. Searle) for 14 days in early October 1973. All ewes were given 2000 i.u. PMSG (Folligon: Intervet) intramuscularly in $5 \mathrm{ml}$ water at the time of withdrawal of the pessaries and were placed with raddled fertile rams. At $24 \mathrm{hr}$ after removal of the pessary, the ewes were assigned to three groups and were treated as follows: Group $1-50 \mu \mathrm{g} \mathrm{Gn}-\mathrm{RH}$ intramuscularly in $1 \mathrm{ml}$ water; Group 2-750 i.u. HCG intramuscularly in $1 \mathrm{ml}$ water (Chorulon: Intervet); Group 3-control (no treatment).

The ewes were inspected each day at 09.00 and 16.00 hours for evidence of mating. At $4 \frac{1}{2}$ to 5 days following removal of the pessaries, the ewes were either slaughtered or subjected to laparotomy and the number of recent CL as well as the number and diameter of unruptured follicles $>3 \mathrm{~mm}$ on each ovary were counted. The sum of the two is referred to as the total ovarian response. Unruptured follicles 3 to $10 \mathrm{~mm}$ in diameter were classed as normal and follicles $>10 \mathrm{~mm}$ in diameter were classified as cystic; these latter follicles were distinctly larger than those classified as normal, and the majority of them were between 13 and $15 \mathrm{~mm}$, although a number of them were $20 \mathrm{~mm}$ in diameter. The oviducts and upper portion of the adjacent uterine horn were flushed for eggs with physiological saline. The flushings were examined immediately for ova and details of their number, stages of cleavage and appearance noted. The ova recovered were fixed in acetic alcohol and stained with lacmoid. The data were analysed by $\chi^{2}$ and analysis of variance procedures with square-root transformation where appropriate.

Three ewes lost pessaries during the treatment period and were discarded from the experiment. The results relate to the remaining forty-one ewes, all of which exhibited oestrus. The estimated interval between pessary withdrawal and onset of oestrus was similar in all groups and averaged $31 \mathrm{hr}$. All the ewes 
ovulated, with the exception of a single individual in Group 1. The ovarian response to the treatments employed is given in Table 1 . There was no significant difference among the treatments either in terms of the mean number of CL. or the total ovarian response. There was a tendency $(P<0 \cdot 25)$ for the proportion of follicles ovulated to be lower in Groups 1 and 2 than in Group 3, the proportion being lowest in Group 2. This proportion was expressed in two ways: (a) total CL per treatment/total response per treatment (per treatment basis), and (b) average for each treatment of the ratio of total CL per animal/total response per animal (per animal basis). Since the animal was the experimental unit, analyses were more appropriately performed on a per animal basis. In the past, however, results have usually been presented on a per treatment basis and, therefore, we present the results both ways in Table 1 . While in the present case

Table 1. Ovarian response of ewes to two superovulation treatments

\begin{tabular}{lccc}
\hline & \multicolumn{3}{c}{ Treatment } \\
\cline { 2 - 4 } & $G n-R H$ & $H C G$ & Control \\
\hline No. of ewes & 16 & 10 & 15 \\
No. of CL & 44 & 21 & 37 \\
No. of unruptured follicles & & & \\
$\quad$ Normal (3 to $10 \mathrm{~mm}$ ) & 18 & 28 & 67 \\
$\quad$ Cystic (11 to 20 mm) & 155 & 99 & 106 \\
Total ovarian response* & $2 \cdot 8 \pm 0 \cdot 38$ & $2 \cdot 1 \pm 0.48$ & $2 \cdot 5 \pm 0 \cdot 39$ \\
Mean no. of GL & $9 \cdot 7 \pm 1 \cdot 54$ & $9 \cdot 9 \pm 1 \cdot 62$ & $7 \cdot 1 \pm 1 \cdot 24$ \\
Mean total ovarian response & & & \\
Ovulations as a proportion & & $0 \cdot 21$ & $0 \cdot 35$ \\
of total ovarian response & $0 \cdot 28$ & $0 \cdot 26$ & $0 \cdot 47$ \\
$\quad$ Per treatment basis & $0 \cdot 43$ & 4 & 19 \\
$\quad$ Per animal basis & 14 & 4 & 14 \\
No. of ova recovered & 8 & 4 & \\
No. of ova fertilized & & & \\
\hline
\end{tabular}

* No. of CL plus number of follicles $>3 \mathrm{~mm}$ in diameter.

the interpretation was not changed by alternative presentation of results, the difference between Groups 1 and 3 was much less on a per animal basis than on a per treatment basis. The distribution of the total ovarian response (CL, normal and cystic follicles) was significantly different in Group $1\left(\chi_{(2)}^{2}=8 \cdot 7 ; P<0.05\right)$ and Group $2\left(\chi_{(2)}^{2}=29.2 ; P<0.01\right)$ from the controls. The difference in the distributions was mainly due to a much higher frequency of cystic follicles ( 11 to $20 \mathrm{~mm}$ in diam.) in the two treatment groups. The ewes in Groups 1 and 2 also had total ovarian responses which differed significantly in distribution $\left(\chi^{2}{ }_{(2)}=11.3 ; P<0.01\right)$, those in Group 2 having more cystic follicles than those in Group 1. The percentage of ewes which had cystic follicles was 25, 40 and 7 for Groups 1, 2 and 3, respectively.

The proportion of ova recovered was significantly lower in the Gn-RH $\left(\chi_{(1)}^{2}=3.2 ; P<0 \cdot 10\right)$ and HCG $\left(\chi_{(1)}^{2}=5 \cdot 8 ; P<0.05\right)$ groups than in the control group. All the fertilized ova recovered had cleaved and the majority of them were at the eight-cell stage. Although the number of ova recovered was too 
small to draw reliable conclusions about differences in fertilization rate, it would appear that neither Gn-RH nor HCG had any detrimental influence on fertilization or ovum development.

The ovulatory response in Group 3 was very low, more than $50 \%$ below that observed by Quirke \& Hanrahan (1973) in ewes of the same breed and in the same season which were given a comparable dose level of PMSG in the follicular phase of the natural cycle. This result differs from those of Gordon (1969) who has reported ovulation rates, in the breeding season, of 3.9 and 4.5 for two groups of Galway ewes which were given approximately 1500 i.u. PMSG (10 i.u./lb liveweight) at the time of progestagen withdrawal or on the 12th day of the natural cycle, respectively. The proportion of follicles which rupture has been found to increase when HCG is given within $3 \mathrm{hr}$ after the onset of oestrus in cyclic sheep stimulated with 750 i.u. PMSG in the follicular phase of the cycle (Killeen \& Moore, 1970). There was no evidence of such an effect in the present work where the time of administration of the HCG was, on average, $7 \mathrm{hr}$ before the onset of oestrus. The release of $\mathrm{LH}$ following injection of Gn- $\mathrm{RH}$ alone has been shown to be ineffective in inducing ovulation in ewes in early and mid-anoestrus but was capable of inducing ovulation in a very high proportion of cyclic ewes with functional CL when given on Day 10 of the cycle at doses of 25 and $100 \mu \mathrm{g}$ (Rippel, Moyer, Johnson \& Mauer, 1974). These authors concluded that the degree of follicular maturation accounted for these differences because very little follicular growth was evident during anoestrus. In view of this conclusion, it was surprising that the dose level of $50 \mu \mathrm{g} \mathrm{Gn}-\mathrm{RH}$ used in the present work did not result in an increased proportion of follicles ovulating.

The incidence of cystic follicles was highest in the Group-2 ewes and was higher in Group-1 than in control ewes; this can perhaps be explained by the follicle-stimulating activity of HCG (Braden, Lamond \& Radford, 1960; Robinson, 1962), and the fact that Gn-RH can release both LH and FSH from the anterior pituitary in the ewe (Reeves, Arimura, Schally, Kragt, Beck \& Casey, 1972).

Administration of $\mathrm{HCG}$ and $\mathrm{Gn}-\mathrm{RH} 24 \mathrm{hr}$ after pessary withdrawal and mild stimulation with PMSG will hasten the time of ovulation in ewes in early anoestrus (J. F. Quirke, unpublished observation). The high oestrogen output of the very large follicles associated with Groups 1 and 2 would also have speeded up the rate of transport of ova through the oviducts. A combination of both of these factors was the probable cause of the lowered ovum recovery rate in these two groups.

The authors wish to thank Dr R. E. Mauer (Abbott Laboratories) for the generous donation of the synthetic Gn- RH (Lot 29-018-Br). The technical assistance of $\mathrm{Mr} \mathrm{K}$. Brooks and $\mathrm{Mr} \mathrm{W}$. Loughnane is acknowledged.

\section{REFERENGES}

Braden, A. W. H., Lamond, D. R. \& RAdford, R. H. (1960) The control of the time of ovulation in sheep. Aust. F. agric. Res. 11, 389-401.

Gordon, I. (1969) Factors affecting response of anoestrous sheep to progestagen treatment. F. Ir. Dept Agric. Fish. 66, 232-267. 
Killeen, I. D. \& Moore, N. W. (1970) The effect of pregnant mare serum gonadotrophin and human chorionic gonadotrophin on ovulation and fertility in the ewe. Aust. F. agric. Res. 21, 807-814.

Quirke, J. F. \& Hanrahan, J. P. (1973) Ovarian response of three ewe breeds to superovulating dose levels of PMSG in the follicular phase of the cycle. Anim. Prod. Res. Report, Agricultural Institute, Dublin. Anim. Prod. Res. Report, p. 164.

Reeves, J. J., Arimura, A., Schally, A. V., Kragt, G. L., Beck, T. W. \& Gasey, J. M. (1972) Effect of synthetic luteinizing hormone-releasing hormone/follicle stimulating hormone-releasing hormone (LH-RH/FSH-RH) on serum LH, serum FSH and ovulation in anestrous ewes. 7. Anim. Sci. 35, 84-89.

Rippel, R. H., Moyer, R. H., Johnson, E. S. \& MAUeR, R. E. (1974) Response of the ewe to synthetic gonadotrophin releasing hormone. F. Anim. Sci. 38, 605-612.

Robinson, T. J. (1962) Gomparative studies of several gonadotrophin, progestin and oestrogen treatments in the anoestrous ewe. $\mathcal{F}$. Endocr. 24, 33-51. 